DEVELOPMENT OF MANAGEMENT AND ENTREPRENEURSHIP METHODS ON TRANSPORT, № 4 (77), 2021
DEVELOPMENT OF MANAGEMENT

AND ENTREPRENEURSHIP METHODS ON TRANSPORT, № 4 (77), 2021
УДК 656.071.4:347.79

JEL Classification K 39

DOI 10.31375/2226-1915-2021-4-68-80

\section{ОРГАНІЗАЦЙННО-ПРАВОВІ ПРОПОЗИЦІї ЩОДО УДОСКОНАЛЕННЯ ДІЯЛЬНОСТІ ПОРТОВИХ ОПЕРАТОРІВ}

О.О. Балобанов

к.ю.н., професор кафедри «Морське право» ORCID: 0000-0002-2586-015X e-mail:ml-bal@ukr.net

А.А. Пальченко

ст. викладач кафедри «Морське право» ORCID: 0000-0001-9686-4660 e-mail:nai-ce@bigmir.net

Одеський національний морський університет, Одеса, Украӥна

Анотація. Правовий статус портових операторів-стивідорів у морських портах Украӥни регулюється за допомогою Кодексу торгівельного мореплавства, Закону Украӥни «Про морські порти України» та Правил надання морських послуг у портах Украӥни. Портова діяльність є складовою сфери торговельного мореплавства і ї̈ правове регулювання пов'язане із діяльністю, що входить у поняття торговельне мореплавство. Світова транспортна система, до якої входять порти функиіонує в умовах загострення конкуренції між начіональними системами, між різними видами транспорту, саме між морським та наземним. В мультимодальному режсмі сьогодні праиюють контейнеризовані, $i$ не контейнеризовані лінії. Стивідорна діяльність включає виробничо-технологічну складову і організаційно-економічну складову. На території кожного морського порту праиюють державні стивідори. Портовий оператор оператор термінала надають послуги з вантажних операчій з вантажами, шо перевозяться водним, залізничним, автомобільним та трубопровідним видами транспорту, а також інших пов'язаних з иим робіт, на замовлення клієнта. Це портовий оператор та оператор термінала. В морських портах Украӥни перелік портових опера торів, операторів терміналів у кожному морському порту, а також перелік послуг, які вони надають визначається в реєстрі морських портів Украӥни. Виходячи з иүієї норми виконавцем вантажних операчій можуть виступати лите портові оператори, оператори терміналів, номенклатура яких обмежена реєстром.

Ключові слова: торгове мореплавство стивідорна кампанія, портовий оператор, морський порт, оператор термінала.

(C) Балобанов О.О., Пальченко А.А., 2021
УДК 656.071.4:347.79

JEL Classification $K 39$

DOI 10.31375/2226-1915-2021-4-68-80

\section{ОРГАНИЗАЦИОННО-ПРАВОВЫЕ ПРЕДЛОЖЕНИЯ ПО УСОВЕРШЕНСТВОВАНИЮ} ДЕЯТЕЛЬНОСТИ ПОРТОВЫХ ОПЕРАТОРОВ

А.О. Балобанов

к.ю.н., профессор кафедры «Морское право» ORCID: 0000-0002-2586-015X e-mail: ml-bal@ukr.net

А.А. Пальченко

ст. преподаватель кафедры «Морское право» ORCID: 0000-0001-9686-4660 e-mail: nai-ce@bigmir.net

Одесский национальный морской университет, Одесса, Украина

Аннотация. Правовой статус портовых операторов-стивидоров в морских портах Украины регулируется с помощью Кодекса торгового мореходства, Закона Украинь «О морских портах Украинь» и Правил предоставления морских услуг в портах Украины. Портовая деятельность является составной частью сферы торгового мореходства и ее правовое регулирование связано с деятельностью, входящей в понятие торгового мореходства. Мировая транспортная система, в которую входят порты, функционирует в условиях обострения конкуренции между национальными системами, между различными видами транспорта, именно между морским и наземным. В мультимодальном режиме сегодня работают и контейнеризированные, $и$ не контейнеризированные линии. Стивидорная деятельность включает в себя производственно-технологическую составляющую $и$ организационно-экономическую составляюшую. На территории каждого морского порта работают государственные стивидоры. Портовый оператор, оператор терминала предоставляют услуги по грузовым операциям с грузами, перевозимыми водным, железнодорожным, автомобильным и трубопроводным видами транспорта, а также других связанных с этим работ по заказу клиента. Это портовый оператор $u$ оператор терминала. $B$ морских портах Украины перечень портовых операторов, операторов терминалов в каждом морском порту, а также перечень предоставляемых услуг определяется в реестре морских портов Украины. Исходя из данной нормы исполнителем грузовых операций могут выступать только портовые операторы, операторы терминалов, номенклатура которых ограничена реестром.

Ключевые слова: торговое мореплавство, стивидорная компания, портовый оператор, морской порт, оператор терминала. 
UDC 656.071.4:347.79

JEL Classification K 39

DOI 10.31375/2226-1915-2021-4-68-80

\title{
ORGANIZATIONAL AND LEGAL PROPOSALS TO IMPROVE THE ACTIVITIES OF PORT OPERATORS
}

\author{
Oleksandr Balobanov \\ Candidate of Law, Professor of the Department of Maritime Law \\ ORCID: 0000-0002-2586-015X \\ e-mail: ml-bal@ukr.net \\ Alla Palchenko \\ Senior Lecturer, Department of Maritime Law, \\ ORCID: 0000-0001-9686-4660 \\ e-mail: nai-ce@bigmir.net
}

Odessa National Maritime University, Odessa, Ukraine

\begin{abstract}
The legal status of port stevedoring operators in the seaports of Ukraine is regulated by the Code of Merchant Shipping, the Law of Ukraine «On Seaports of Ukraine» and the Rules for the provision of sea services in the ports of Ukraine. Port activity is an integral part of the sphere of merchant shipping and its legal regulation is associated with activities that are part of the concept of merchant shipping. The world transport system, which includes ports, operates in conditions of intensified competition between national systems, between different modes of transport, namely between sea and land. Both containerized and non-containerized lines operate in multimodal mode today. Working as part of a multimodal scheme requires seaports stevedores to be competitive, both in relation to the subjects of movement of goods, and to the ports included in other logistics chains. Stevedoring activities are part of economic activities. It should be considered as the activity of business entities, which is associated with the loading and unloading of ships, aimed at generating income, is regular, permanent, significant, that is, it coincides with the definition of entrepreneurial activity. Stevedoring activities include a production and technological component and an organizational and economic component. As a reality on the grounds of modernization in the development of the world port distribution system, the process of attracting private capital not only in the development of port infrastructure, but also in the actual stevedoring activities. State stevedores operate on the territory of each seaport. The port operator, the terminal operator provide services for freight operations with goods transported by water, rail, road and pipeline modes of transport, as well as other related work at the request of the client. That is, there are two definitions regarding the executor of cargo operations. These are the port operator and the terminal operator. In the seaports of Ukraine, the list of port operators, terminal operators in each seaport, as well as the list of services provided is determined in the register of seaports of Ukraine. Based on this rule, the executor of cargo operations can be only port operators, terminal operators, whose range is limited to the register.

Keywords: merchant shipping, stevedoring company, port operator, seaport, terminal operator.
\end{abstract}

Постановка проблеми. Стратегія розвитку портів на базі реформування портової галузі має враховувати світові та європейські тенденції щодо організації портів як логістичних центрів світової торгівлі. У сфері поліпшення надання послуг портових операторів-стивідорів необхідно 
також усунення різноманітних недоліків, пов'язаних з залученням нових клієнтів та інвестицій. Виявляється необхідність чітко визначитися щодо правового регулювання стивідорської діяльності та шляхів iï інвестування, розвитку, організації. Виявляється необхідність з'ясувати правовий статус Реєстру портових операторів у складі морських портів.

Огляд останніх досліджень та публікацій. Важливі питання досліджуваної проблеми розглядалися в працях вітчизняних учених, зокрема, у роботах О.М. Кібік, О.М. Кіфака, В.В. Коваля, О.М. Котлубая, О.П. Підцерковного та інших. Водночас необхідність дослідження процесів господарювання в морських портах не втрачає своєї актуальності. Світова ринкова кон'юнктура постійно змінюється, процеси глобалізації та інтернаціолізації поглиблюються, перед світом постають нові проблеми, зокрема, у вигляді світової пандемії COVID-19. Ці фактори впливають на всі сфери людського буття, на соціальний та економічний складники. Саме тому в умовах швидких економічних, правових, соціальних змін розгляд сучасних напрямів розвитку господарської діяльності в морських портах видається вельми цікавим та необхідним.

Завданням дослідження с вивчення основних проблемних питань та напрямів розвитку та діяльності портових операторів-стивідорів. Дослідження світових тенденцій функціонування морегосподарського комплексу, аналіз правових засад та проблематики функціонування логістичних центрів світової морської торгівлі.
Основний матеріал дослідження. Посилення комерційної стивідорської функції портів, поряд 3 функціями адміністративною та безпековою, отримали в світі повне визнання, що, в свою чергу, перетворює їх на логістичні центри світової морської торгівлі. Останнім часом головним викликом портам-стивідорам $\epsilon$ формування світової транспортної системи, що забезпечує світову логістику. 3 сучасної практики морські порти на міжнародному та європейському рівнях є багато-функціональними об'єктами, які, 3 точки зору, ï участі у логістичних процесах забезпечують міжнародну торгівлю. Порти - $є$ логістичними центрами, у яких поєднуються функції перевезення, перевантаження, зберігання та інших господарських операцій. У порту, як логістичному центрі, стикаються інтереси практично усіх суб'єктів морського бізнесу (судновласників, вантажовласників, стивідорів, сервісних організацій, контролюючих органів, тощо). Маємо деталізувати визначення порту, як логістичного центру наступним чином:

1. Центр логістичного ланцюга, де починаються та завершуються правовідносини між суб'єктами світової торгівлі (наприклад, це місце переходу права власності на товар, кордон розподілу ризиків, обов'язків та витрат за правилами торгівлі);

2. Логістичний центр, де стикаються функції перевезення, перевалки, зберігання, щодо обслуговування вантажів та транспортних засобів (в першу чергу - морських суден);

3. Центр стикання комерційних та юридичних інтересів осіб, що $є$ 
операторами зазначених засобів;

4. Центр взаємодії різних видів транспорту, особливо під час мультимодальних перевезень;

5. Центр прийняття організаційно-правових та управлінських рішень;

6. Центр де здійснюється юридичне закріплення, оформлення правовідносин та розв'язання конфліктів інтересів через спеціальні договори, або на основі нормативно-правових документів;

7. Центр стикання функцій забезпечення безпеки та суто комерційних функцій;

8. Центр стикання обов'язків держави прапору судна та держави порту;

9. Центр, де контролюється виконання вимог міжнародних угод судновласниками та висвітлюються проблеми їх імплементації державами;

10. Кордон митних, санітарних, безпекових, пошуково-рятувальних зон відповідальності, що встановлює держава порту.

Тобто, порт є, 3 одного боку, географічним місцем - 3 акваторією та територією за законом, а $з$ другого боку, - транспортним комплексом, системою спеціалізованих послуг, що надаються у портовій виробничій зоні, 3 третього боку, логістичним центром, яке у розумінні міжнародної торгівлі (ланцюга поставок), так і в розумінні логістичних послуг (переміщення, складування, сервісу).

Світова транспортна система, до якої входять порти, функціонує в умовах загострення конкуренції між національними системами, головним чином - між різними видами транспорту, саме між морським та назем- ним. В мультимодальному режимі сьогодні працюють і контейнеризовані, і неконтейнеризовані лінії. Робота у складі мультимодальної схеми вимагає від морських портів стивідорів бути конкурентоздатними, як у відношенні до суб'єктів переміщення товарів, так і до портів, що входять до інших логістичних ланцюгів.

Ще одним важливим впливом на порти $є$ активізація процесів економічної інтеграції держав та регіонів, що в свою чергу інтегрує порти у міжнародну і міжрегіональну економіку.

Таким чином, агресивність зовнішнього середовища по відношенню до портів зростає i ця тенденція зберігається, але, в будь-якому разі, ефективність порту визначається запитами клієнтів - продавців та покупців товарів на світовому ринку. У цих умовах, порт-стивідор має розробити активну стратегію, яка дозволить йому отримати переваги за рахунок якості робіт та широкої диверсифікації послуг. Такі можливості дає розвиток як менеджменту, так і інфраструктури. Якщо раніше основним критерієм розвитку порту виступала саме його інфраструктура, то тепер ще й управління та інформаційна система. Головними суб'єктами, що спонукають та забезпечують розвиток, $є$ портові оператори, які працюють в його складі і надають стивідорські та інші послуги.

Така ситуація диктує необхідність забезпечити якісну нормативноправову базу, що пов'язана 3 діяльністю портового господарства, в першу чергу стосовно стивідорів та стивідорської діяльності, портових 
операторів та послуг, що ними надаються, та терміналів, термінальних операцій, операторів терміналів. На жаль, законодавство України не в повній мірі відповідає світовій практиці та реальним місцевим вимогам.

Стивідорна діяльність $є$ частиною господарської діяльності. Її слід розглядати як діяльність суб'єктів господарювання, що пов'язана 3 навантаженням-розвантаженням суден, направлена на отримання доходу, $\epsilon$ регулярною, постійною, суттєвою, тобто це цілком співпадає з визначенням підприємницької діяльності. Стивідорна діяльність включає виробничо-технологічну складову i організаційно-економічну складову. Як реальність 3 мотивів модернізації у розвитку світової портової системи розповсюдження отримав процес залучення приватного капіталу не тільки у розбудову інфраструктури порту, але й власне в стивідорну діяльність. В даний час, в світі та в Європі $\epsilon$ різноманітні форми збільшення ролі приватного сектору у стивідорній діяльності. Вона торкається вантажорозвантажувальних робіт, логістичних операцій, а також буксирування, швартування, агентських послуг. 3 урахуванням роботи в більшості випадків державних стивідорних кампаній та впливу держав через Адміністрацію портів, участь приватного сектору відображається через:

- створення спільного підприємства Адміністрацією порту та стивідорною кампанією;

- контракт між портовою владою та приватними підприємствами для експлуатації окремих терміналів порту (менеджмент, управління майном);
- передача в концесію частини портових споруд або терміналу. Термінали передаються в концесію на певний строк приватній фірмі, яка фінансує суперструктури та техніку, забезпечує експлуатацію та отримує прибуток відповідно до контракту;

- концесія, коли контракт укладається між державним власником та приватним вкладником капіталу, який фінансує, будує, експлуатує і отримує прибуток протягом встановленого періоду конкретний портовий термінал. При цьому, територія залишається у власності держави, якій повертаються усі споруди;

- оренда терміналів. На практиці використовується оренда трьох типів: довгострокова (20-50 років), короткострокова (3 місяця - 1 рік), разова (для розвантаження окремого судна). Європейськими портами встановлені певні правила по кожному типу оренди, основними умовами яких $\epsilon$ забезпечення конкуренції i виключення приватної монополії.

Великим судновласникам і вантажовласникам вигідно, коли стивідорні кампанії належать повністю або частково їм. Це гарантує повний обсяг стивідорних операцій, що забезпечує зайнятість та прибутковість. Тобто зазначені суб'єкти приводять 3 собою вантажопотік і самі $з$ ним працюють.

Агентські кампанії також прагнуть вкладати капітал в стивідорний бізнес, як і стивідорні в агентський. Але в певних випадках створюється конфлікт інтересів між стивідором та судновласником, на користь якого має працювати агент.

Стивідорні кампанії Свропейського типу перестають бути уні- 
версальними та спеціалізуються по видах оброблювальних вантажів, типах суден та характеристиках ліній (до складу яких, зазвичай входить i стивідор). У великих портах світу стивідорні кампанії об'єднуються в Асоціації, які представляють та відстоюють їх інтереси судновласниками, профспілками, а також розробляють єдину політику щодо тарифів на стивідорні операції. Асоціації об’єднують стивідорні кампанії одного порту або групи портів.

Якщо говорити про державні портові оператори, то на території кожного морського порту працюють державні стивідори. Наприклад, у порту «Південний» здійснює державну стивідорну діяльність держкомпанія «Морський торговельний порт (МТП) «Південний». ДП МТП «Південний» $\epsilon$ найбільшим (за вантажообігом) і найглибшим портом в Україні. Порт займає вигідне економіко-географічне розташування. Він знаходиться в самому центрі Причорномор'я має вихід в регіон Середземного моря, близько розташований до основних залізничних магістралей держави, 3 щорічною навігацією і можливістю прийому сучасного крупнотонажного флоту. Вказані переваги дозволяють здійснювати ефективні експортно-імпортні перевезення вантажів через порт України та збільшувати обсяги переробки транзитних вантажів для інших держав. При розробці стратегії для морського порту ДП МТП «Південний» важливо виявити можливості і загрози, а також оцінити сильні та слабкі сторони.

До сильних сторін відносять:

1. Глибини біля причалів більш 18 м, що робить порт самим глибо- ководним в Україні.

2. «Південний» - незамерзаючий порт з цілорічною навігацією.

3. У 2013 році порт завершив трирічну програму поповнення портового флоту.

4. Проводить сприятливу соціальну політику.

5. Здійснюється інвестиційний план порту, котрий передбачає модернізацію перевантажувальних комплексів, реконструкцію колійного господарства, модернізацію кранів i технологічного транспорту.

До слабких сторін відносять:

1. Здійснення роботи, в тому числі 3 шкідливими речовинами, виробленими Одеським припортовим заводом.

2. Високий рівень плинності кадрів управлінського персоналу.

3. Протекціонізм в підборі кадpiB.

4. Важкі умови праці працівників вантажних робіт.

Можливості порту виявляються в:

1. Зростанні обсягів вантажопотоків, виникненні нових сегментів ринку по вантажах.

2. Розширенні міжнародних потоків капіталу в формі прямих інвестицій в порт.

3. Прийомі на роботу молодих фахівців 3 новим підходом до вирішення проблем.

4. Удосконаленні державного регулювання в транспортній галузі.

5. Зростанні світової і регіональної економіки.

Загрози в діяльності МТП «Південний» виявляються в:

1. Посиленні конкуренції 3 боку найближчих портів. 
2. Нестабільності та недосконалості економічного законодавства i поточної економічної ситуації, умовах інвестування і використання прибутку.

3. Недосконалості правової бази, яка регламентує взаємини учасників міжнародних і внутрішніх перевозок.

4. Нестабільності політичної ситуації.

5. Недостатньому рівні зовнішніх інвестицій в розвиток портової інфраструктури.

Незважаючи на складний інвестиційний клімат і недостатність власного капіталу, в Україні реалізуються інфраструктурні інвестиційні проекти, спрямовані на розвиток портової діяльності, залучаються з недержавних коштів, вітчизняних та іноземних інвесторів. Розвиваються схеми державно-приватного партнерства. Стрімкий розвиток портового господарства в умовах жорсткої конкуренції можливий лише в разі тісної співпраці порту із державою і залучення інвестицій у розвиток порту для досягнення максимальної ефективності. Отже, основні напрямки розвитку вантажних робіт порту мають відповідати перспективам збільшення вантажопотоків, виходити 3 економічних інтересів держави, порту та регіонів розташування. Таким чином, стратегія розвитку ДП МТП «Південний» має бути спрямована насамперед на вирішення наступних задач: ління;

- оптимізації структури управ-

- створення сучасної вантажної бази портів та портової інфраструктури;
- розвитку інвестиційно-інноваційної діяльності;

- залучення фінансових ресурсів;

- удосконалення тарифної політики;

- удосконалення системи митного контролю;

- підвищення ефективності функціонування портів;

- підвищення ролі соціальної складової у діяльності портів.

Основною при реформуванні стратегічного управління логістичною діяльністю ДП «МТП «Південний» повинна бути стратегія інтеграції, націлена на формування логістичних ланцюгів транспортних та вантажних потоків від їхнього виникнення до кінцевого споживача. Ця комплексна стратегія має враховувати стратегічні задачі, які ставлять перед собою окремі функціональні сфери діяльності МТП, що мають специфічні для них стратегії. Так, основною задачею стратегії мінімізації витрат є скорочення оперативних витрат в усіх логістичних функціях, в першу чергу на основі процесів складування та перевантаження. Вирішенню цієї задачі сприятиме реалізація стратегії операційної системи порту - мінімізації інвестицій в логістичну інфраструктуру, яка базується на пріоритеті «кроссдокінгу» - тобто прямої доставки вантажів споживачам, без складування, застосування системи логістичної доставки «точно в строк», оптимального розміщення логістичної інфраструктури. Відповідно до стратегії покращення якості логістичного сервісу основною задачею $\epsilon$ покращення якості всіх логістичних функцій на основі створення системи 
логістичного сервісу. Побудова мультимодального логістичного центру на базі ДП «МТП «Південний» має грунтуватися на наступних вихідних положеннях:

- портовий комплекс України у цілому та ДП «МТП «Південний» зокрема відчувають дефіцит потужностей для перевалки навалювальних вантажів;

- найбільшим попитом користуються глибоководні термінали;

- для забезпечення енергетичної безпеки України виникає необхідність і у будівництві потужних, технологічно ефективних і глибоководних терміналів для перевалки вугілля та скрапленого газу;

- у зв'язку з ситуацією на сході країни різко збільшились обсяги каботажних перевезень;

- подальша реалізація інвестиційних проектів розвитку портової інфраструктури сприятиме зростанню обсягів перевалки транзитних, експортно-імпортних вантажів i зміцнить конкурентоспроможність МТП.

Врегулювання проблеми портового оператора важлива саме 3 конкурентної атмосфери та взаємодії 3 користувачами та Адміністрацією Порту. 3 приводу, правового статусу портового оператора маємо численні коментарі, але спори та суперечки ще мають місце. Основою чіткого визначення правового статусу Портового оператора має бути відокремлення його від інших суб'єктів портової діяльності, користувачів, порядку реєстрації, прив'язки до певних функцій, акваторії, території. Маємо визначатися через наукові дослідження, судові рішення та уточнення у законодавстві. Нажаль, на теперішній час в повній мірі цього не має. В Україні основним законом, що регулює правовідносини у сфері мореплавства $\epsilon$ Кодекс торговельного мореплавства України. Під торговельним мореплавством розуміється діяльність 3 використання суден для перевезення вантажів та ін. Оскільки перевезень без перевалки, зберігання, накопичення обслуговування вантажів не може бути, то портова діяльність у визначенні морських законодавств світових держав та України є складовою сфери торговельного мореплавства. Слід відзначити і ст. 4 КТМ, яка відносить регулювання морських правовідносин не тільки до морського кодексу, а й до правил цивільного, адміністративного, господарського та іншого законодавства України [1]. Це положення цілком відноситься до портового регулювання, у якому портовий оператор $\epsilon$ центральним суб'єктом, тобто діяльність цього суб'єкта має бути врегульована не тільки спеціальними, а й загальними нормами права. У даному випадку, спеціальні норми права сконцентровані в Законі України «Про морські порти України» та підзаконних актах щодо портової діяльності [2].

Портовий оператор, оператор термінала надають послуги 3 вантажних операцій 3 вантажами, що перевозяться водним, залізничним, автомобільним та трубопровідним видами транспорту, а також інших пов'язаних з цим робіт на замовлення клієнта. Тобто існує дві дефініції щодо виконувача вантажних операцій. Це портовий оператор та оператор термінала.

Оператор термінала на відміну від визначення портового оператора - 
суб'єкт господарювання, що здійснює у морському порту вантажні операції, обслуговування та зберігання вантажів, обслуговування транспортних засобів, а також інші пов'язані з цим види господарської діяльності за межами морського терміналу. Тобто 3 визначення оператора термінала можна зробити висновок, що і він може бути віднесений до категорії суб'єктів стивідорської діяльності взагалі, але 3 використанням терміналів - тільки у співпраці з портовим оператором.

3 точки зору європейської практики визнається, що оператор терміналу може виконувати лише внутрішні термінальні операції, але не стивідорні, які 3 судном виконуе портовий оператор. Якщо робиться така диференціація, то треба визначити ці поняття у законодавстві, але за явної потреби виробництва. Тим більше оператор морського терміналу $\epsilon$ особою, що здійснює його експлуатацію. Тобто експлуатація і операторство - це взаємопов'язані поняття. Тому маємо окремо тлумачити саме поняття експлуатація морського термінала. Під цією експлуатацією слід розуміти безпосереднє та безперешкодне володіння та користування морським терміналом, яке базується на певному речовому, зобов'язальному праві у кожному морському порту.

Відповідно до п. 3.1 Правил надання послуг в морських портах України перелік портових операторів, операторів терміналів у кожному морському порту, а також перелік послуг, які вони надають, визначається в реєстрі морських портів України [3]. Виходячи з цієї норми, виконавцем вантажних операцій мо- жуть виступати лише портові оператори, оператори терміналів, номенклатура яких обмежена реєстром. Ст. 6 Закону України «Про морські порти» передбачається обов'язковість ведення такого реєстру. Відомості, що вносяться до реєстру, включають, крім загально-портових, такі, як повне найменування, місце знаходження, перелік причалів послуг, технічні характеристики термінала [2]. Ведення реєстру покладено на АМПУ. Таким чином відповідальність за реєстрацію портових операторів та операторів терміналів за певними організаційно-технічними ознаками де-юре покладена на АМПУ, а дефакто - це й контроль за їх діяльністю. Хоча достовірність та повноту інформації забезпечують самі суб'єкти господарювання, АМПУ завжди може перевірити, що, нажаль, часто не відбувається. Хоча стивідорна діяльність згідно 3 законодавством України не потребує ліцензування (крім обробки небезпечних вантажів), але порядок у порту - справа АМПУ, і він безумовно включає уточнення інформації щодо суб'єктів портової діяльності.

Висновки. Таким чином, основними висновками 3 наведеного можна вважати:

1. Стратегія розвитку портів на базі реформування портової галузі має враховувати світові та європейські тенденції щодо організації портів як логістичних центрів світової торгівлі.

2. Маємо чітко визначитися щодо правового регулювання стивідорської діяльності та шляхів іiі інвестування, розвитку, організації.

3. Потрібно підвести підсумки 
правозастосувальної практики щодо виконання Закону України «Про морські порти» та підзаконних актів, принаймні стосовно діяльності портових операторів та операторів терміналів у договірних правовідносинах 3 вантажовласниками та іншими суб'єктами морського бізнесу.

4. Маємо з'ясувати правовий статус Реєстру портових операторів у складі морських портів.

В сфері поліпшення надання послуг портових операторів-стивідорів необхідно також усунення різноманітних недоліків. Але вишукування проблем в цій галузі їі не оновить і не дасть поштовху для подальшого розвитку. Ефективним може стати багатостороння допомога у стивідорній діяльності, залучення нових клієнтів та інвестицій.

У будь-якій діяльності $\epsilon$ недоліки, які необхідно усувати i перспективи, які потрібно розвивати. Діяльність стивідорних компаній також $\epsilon$ діяльністю 3 перспективами розвитку, але усунувши перешкоди тільки цілком можливо одержати збільшення суднопотоку, покращити якість портових послуг, вийти на міжнародний рівень і конкурувати 3 іншими морськими портами Східної Європи. Морські порти нашої країни мають велике майбутнє, потужний кадровий потенціал, який в майбутньому, за умов обрання вірного шляху розвитку, відновить вітчизняні морські порти у колі лідерів портової галузі.

\section{СПИСОК ЛІТЕРАТУРИ}

1. Кодекс торгового мореплавства Украӥни: Закон Украӥни від 23.05.1995 р. // Відомості Верховної Ради України. 1993. № 47.

2. Про морські порти України: Закон України від 17.05.2012 р. № 4709-УI // Офічійний вісник України. - 2012. - № 45.

3. Про затвердження Правил надання морських послуг у портах Украйни: Наказ Міністерства інфраструктури України від 05.06.2013 р. № 348 // Офіиійний вісник Украӥни. 20I3. № 65.

4. Гришина Л.О., Карась П.М., Філіпішина Л.М. Тенденції, проблеми та перспективи розвитку морегосподарського комплексу України в умовах євроінтеграчії// Науковий вісник УНУ. 2019. Вип. 24. Ч. 1. С. 131-135.

5. Морська доктрина України на період до 2035 року. URL: https:// zakon.rada.gov.ua/laws/ show/1307-2009-\%D0\%BF\#Text

6. Манаєнко I.М., Просяник I.В. Особливості зовнішньоекономічної діяльності вітчизняних підприємств в умовах євроінтеграиії // Науковий вісник Ужгородського національного університету. 2018. Вип. 18. Ч. 3. C. 11-14.

7. Рыженкова Н. Грузооборот в портах Украины вырос на 3,7 \% // Порты Украины. 2020. № 8 (200). С. 36-41. 
8. Статут Державного підприємства «Адміністраиія морських портів України».URL:https://mtu.gov.ua/files/\%D0\%A1\%D1\%82\%D0\%B0\%D1\%82\%D1\%83 $\% D 1 \% 82 \% 20$.

9. Проект Закону України «Про корпоратизацію Адміністрації морських портів України» 2019 p. URL: https://mtu.gov.ua/projects/246/.

10. Дюемал Инаишвили. Мы видим Херсонский порт как крупный региональный хаб // Порты Украины. 2020. № 6 (198). С. 8-9.

11. Порядок відрахування до державного бюджету частини чистого прибутку (доходу) державними унітарними підприємствами та їх об'єднаннями: Постанова KMУ від 23 лютого 2011.№138. URL:https://zakon.rada.gov.ual laws/ show/138-2011-\%D0\%BF\#Text.

12. Работнев Владимир. Каким быть морфлоту Украины в 2030 году // Порты Украины. 2020. № 6 (198). С. 20-24.

13. Проєкти Методики розрахунку розмірів ставок портових зборів, які справляються у морських портах та Порядку справляння, обліку та використання коштів від портових зборів, крім використання коштів від сплати адміністративного збору від 10 квітня 2020 року. URL: https://mtu.gov.ua/news/31784.html

14. Priorities of European ports for 2019-2024: Memorandum of the European Sea Ports Organisation for the new Commission and European Parliament. URL: https://www.espo.be/media/Memorandum\%20ESPO \%20FINAL\%20Digital\%20 version.pdf

15. Оновлена Стратегія розвитку морських портів до 2038 року від 23.12.2020 p. URL: http://www.uspa.gov.ua/pres-tsentr/novini/novini-galuzi/ 18137-skhvaleno-onovlenu-strategiyu-rozvitku-morskikh-portiv-do-2038-roku-mininfrastrukturi

16. Про кониесію: Закон України від 03.10.2019 № 155-ІХ. Відомості Верховної Ради України. 2019. № 48. Ст. 32.

17. Directive 2014/23/EU of the European Parliament and of the Council of 26 February 2014 on the award of concession contracts. OJ L 34, 28.3.2014. P. 1-64.

18. Communication from the Commission Guidance to the Member States concerning foreign direct investment and free movement of capital from third countries, and the protection of Europe's strategic assets, ahead of the application of Regulation (EU) 2019/452 (FDI Screening Regulation) 2020/C 99 I/01. OJ C 33I, 26.3.2020. P. 1-5.

\section{REFERENCES}

1. Code of Merchant Shipping of Ukraine: Law of Ukraine of 23. 05. 1995 // Bulletin of the Verkhovna Rada of Ukraine. 1993. № 47 [in Ukrainian].

2. On seaports of Ukraine (2012): Law of Ukraine of 17.05.2012 № 4709-UI // Official Gazette of Ukraine. № 45 [in Ukrainian]. 
3. On approval of the Rules for the provision of maritime services in the ports of Ukraine (2013: Order of the Ministry of Infrastructure of Ukraine dated 05.06.2013 № 348 // Official Gazette of Ukraine.№ 65 [in Ukrainian].

4. Grishina, L.O., Karas, P.M. \& Filipishina, L.M. (2019). Trends, problems and prospects of development of the maritime complex of Ukraine in the conditions of European integration. Scientific Bulletin of UNU. Vip. 24. Ch. 1. P. 131-135 [in Ukrainian].

5. Maritime Doctrine of Ukraine for the period up to 2035. Retrieved from: https://zakon.rada.gov.ua/laws/show/1307-2009-\%D0\%BF\#Text [in Ukrainian]

6. Manaenko, I.M.. \& Prosyanyk, I.V.. (2018). Features of foreign economic activity of domestic enterprises in the conditions of European integration. Scientific Bulletin of Uzhhorod National University. Vip. 18. Ch. 3. P. 11-14 [in Ukrainian].

7. Ryzhenkova, N. (2020). Cargo turnover in the ports of Ukraine increased by $3.7 \% / /$ Ports of Ukraine. № 8 (200). P. 36-41 [in Ukrainian].

8. Charter of the State Enterprise "Administration of Seaports of Ukraine». Retrieved from: https: I/mtu.gov.ualfiles $\%$ D $0 \%$ A1\% D1\%82\%D0\%B $\%$ D $1 \%$ $82 \% D 1 \% 83 \% D 1 \% 82 \% 20$ [in Ukrainian].

9. Draft Law of Ukraine "On Corporatization of the Seaports Administration of Ukraine» 2019 URL: https://mtu.gov.ua/projects/246/ [in Ukrainian].

10. Jemal Inaishvili. We see the port of Kherson as a major regional hub // Ports of Ukraine. 2020. № 6 (198). P. 8-9 [in Ukrainian].

11. The procedure for deducting to the state budget part of the net profit (income) by state unitary enterprises and their associations: Resolution of the Cabinet of Ministers of February 23, 2011. №138. URL: https: //zakon.rada.gov.ua/laws/ show/138-2011-\%D0\%BF\#Text [in Ukrainian].

12. Rabotnev Vladimir. How to be the navy of Ukraine in 2030 // Ports of Ukraine. 2020. № 6 (198). P. 20-24 [in Ukrainian].

13. Draft Methods for calculating the rates of port fees charged at seaports and the Procedure for collection, accounting and use of funds from port fees, except for the use of funds from the payment of administrative fees from April 10, 2020. URL: https://mtu.gov.ua/news/31784.html [in Ukrainian].

14. Priorities of European ports for 2019-2024: Memorandum of the European Sea Ports Organization for the new Commission and European Parliament. Retrieved from: https://www.espo.be/media/Memorandum\%20ESPO\% 20 FINAL\%20Digital\%20 version.pdf [in Ukrainian].

15. Updated Strategy for the development of seaports until 2038 from 23.12.2020. Retrieved from: http://www.uspa.gov.ua/pres-tsentr/novini/novini-galuzi / 18137-skhvaleno-onovlenu-strategiyu-rozvitku- morskikh-portiv-do-2038-rokumininfrastrukturi [in Russian]. 
16. On the concession: Law of Ukraine of October 3, 2019 № 155-IX. Information of the Verkhovna Rada of Ukraine. 2019. № 48. Art. 32 [in Ukrainian].

17. Directive 2014/23 / EU of the European Parliament and of the Council of 26 February 2014 on the award of concession contracts. OJ L 34, 28.3.2014. P. 1-64.

18. Communication from the Commission Guidance to the Member States concerning foreign direct investment and free movement of capital from third countries, and the protection of Europe's strategic assets, ahead of the application of Regulation (EU) 2019/452 (FDI Screening Regulation) 2020 / C 99 I / 01. OJC 33I, 26.3.2020. P. 1-5.

\section{Стаття надійшла 08.11.2011}

Посилання на статтю: Балобанов О.О., Пальченко А.А. Організаційно-правові пропозиції щодо удосконалення діяльності портових операторів // Розвиток методів управління та господарювання на транспорті: Зб. наук. праць, 2021. № 4 (77). С. 68-80. DOI 10.31375/2226-1915-2021-4-68-80.

Reference a JournalArtic: Balobanov, Oleksandr \& Palchenko, Alla. (2021). Organizational and legal proposals to improve the activities of port operators // Development of management and entrepreneurship methods on transport. 4 (77), 68-80. DOI 10.31375/22261915-2021-4-68-80. 